\title{
Ethnologies
}

\section{A History of Domestic Space: Privacy and the Canadian Home. By Peter Ward. (Vancouver and Toronto: University of British Columbia Press, 1999, ix + 182 p., black/white photographs, colour plates, reference notes, index, CAN \$39.95, ISBN 0-7748-0684-2)}

\section{Michele L. Gillingham}

Volume 24, numéro 2, 2002

Musées

Museums

URI : https://id.erudit.org/iderudit/006652ar

DOI : https://doi.org/10.7202/006652ar

Aller au sommaire du numéro

Éditeur(s)

Association Canadienne d'Ethnologie et de Folklore

ISSN

1481-5974 (imprimé)

1708-0401 (numérique)

Découvrir la revue

Citer ce compte rendu

Gillingham, M. L. (2002). Compte rendu de [A History of Domestic Space: Privacy and the Canadian Home. By Peter Ward. (Vancouver and Toronto: University of British Columbia Press, 1999, ix + 182 p., black/white photographs, colour plates, reference notes, index, CAN \$39.95, ISBN 0-7748-0684-2)]. Ethnologies, 24(2), 253-256. https://doi.org/10.7202/006652ar d'utilisation que vous pouvez consulter en ligne. 
We Came from over the Sea: British War Brides in Newfoundland and The Women of Fogo Island: Hear them speak are about life in the raw and are presented from a grassroots type of approach. These texts are not only tributes to the women and their contribution but they give prominence to the informants. The informants are being valued without being overshadowed by academic interpretations. The importance of these books for future generations has been increased because the maiden names of the informants were included where possible. In addition, potential studies of the interplay of cross-cultural dynamics may be of interest to researchers in this area. This is due to the stark contrast between the women's social backgrounds. The women in Newfoundland and Fogo behaved according to paternalistic ideals. Without a doubt the transition of the war brides into this type of culture was difficult. They were of a different mind set, for many of them had been professionals or enlists in their own country.

In conclusion, as these texts illustrate, women enjoyed and endured life, demonstrated resilience in the face of difficulty, and rose to the challenge of what needed to be done. It is refreshing to see this kind of grassroots effort to publish women's stories; for it definitely raises the profile and the awareness of women's personal experience narratives. These wonderful renditions of women's experiences do not fall into the trap of glorifying the past. Instead, they are symbolic of that which is intangible, and of that which will surely fade from view if more in depth studies are not soon undertaken.

Heather King

Memorial University of Newfoundland

A History of Domestic Space: Privacy and the Canadian Home. By Peter Ward. (Vancouver and Toronto: University of British Columbia Press, 1999, ix + 182 p., black/white photographs, colour plates, reference notes, index, CAN \$39.95, ISBN 0-7748-0684-2)

Peter Ward proposes two goals in this book. First, he intends to demonstrate how Canadian domestic architecture over the last three centuries has shaped and has been shaped by family and social relationships. Second, he argues that the changing form, setting and domestic technology of the home has profoundly impacted individual privacy both within the home and the community. Underlying his 
intentions is the notion that the home is the place where "people spend their lives"(3).

The first chapter, "Housing and Privacy," is a brief introduction to the relationship between privacy and the home. Ward distinguishes between two types of privacy: personal privacy which "sets the individual apart from the group, creating opportunities for seclusion," and family privacy which "creates a boundary between itself and the larger community"(6). It is Ward's intent to illustrate the way in which domestic architecture is divided into private and public spaces.

Ward goes on to examine the form, size and development of the domestic interior of the Canadian home over the last 300 years. He analyzes aspects such as crowding, organization of space and the effects of domestic technology on personal privacy. He also presents each of the "primary" domestic rooms in turn: bathroom, bedroom, parlour and kitchen. He concludes with a discussion on the apartment as domestic space, both in past and present times.

Ward makes several interesting points in this chapter as he traces the development of domestic forms from 1-2 room dwellings to homes consisting of rooms dedicated to specialized functions. He also considers the evolution of heating and lighting sources into their modern forms and their impact on increasing privacy in the home. Family members no longer needed to gather around a central heat and light source and could retire to other rooms in the house.

Ward also considers the relation of status to the organization of space in the home. He argues that the parlour, for example, represented the family's tastes, interests, status, possessions and cultural standing. It usually contained a piano, a "mark of prosperity" of the well off, and a hearth, traditionally the central gathering space for the family. While the presence of pianos in the parlour is decreasing, the presence of the hearth retains a symbolic role in the living area of many homes.

The kitchen of today is typically segregated from the rest of the home, with the exception of homes utilizing the open-air plan. Ward, with a nod to gender theory, suggests that as the kitchen was separated from the rest of the family social areas, so was the housewife. Ward also points out that as housing sizes increased, sleeping areas were allocated based on authority, age and sex, the parents possessing their own room and the children separated by sex in the other rooms. By the twentieth 
century, family size started to decrease as well, creating the opportunity for each member, excepting the parents, to have their own room, and thus more privacy.

In chapter three, "The House and Its Setting," Ward traces the changes in house settings, building regulations and the development of the exterior counterparts of the home, the yard, deck and verandah. In the eighteenth century, farmhouses were built close together and near the road. By the late nineteenth century, houses were set back from the road and at a distance from neighbors. Physical barriers, such as hedges, were constructed, imposing boundaries between houses. The country villa developed at this time as a "retreat from urban life... for pleasure and relaxation in a rustic setting" (105). The early city houses were set close to the road and in close proximity to their neighbors. Urban overcrowding led to the establishment of the suburban home. But by the nineteenth century town planning organizations were instituting laws and regulations for the placement of homes. The result was the uniform placement of homes, at set distances from neighbors, and surrounded by garden lots. The front of the home was dedicated to an expanse of lawn and family activities migrated to the back of the home on verandahs and decks, removed from public view.

Ward concludes his book by reiterating his main points. However one new point emerges: the development of communication technology - radio, telephone, television, fax, Internet - has altered the notion of privacy. With these technologies, he argues, we have brought the world into our homes and blurred the distinction between the private and the public.

I enjoyed reading this book. Ward writes in a comprehensible manner. The book is not filled with jargon and technical terminology and is accessible to layperson and scholar alike. Ward also provides very specific examples of people, their homes and settings which strengthen his points and personalizes his research. His liberal use of photographs, colour prints, housing diagrams and maps relates equally well to the data and the book becomes more that a mere recounting of facts.

Ward bases his work on numerous resources: census data, demographic studies, special collections, and museums. As a result, the book offers an interdisciplinary perspective that touches on aspects of history, folklore, archeology, sociology and gender theory. He is also 
careful to critically examine his sources and to present any potential limitations.

While this book focuses on trends and patterns in the development of domestic architecture over a three-century period, Ward is careful to point out the exceptions. He cautions the reader to remember that this development occurred at different paces for different economic levels. One point I would like to note, however, is that while Peter Ward does touch on the impact of gender on domestic architecture, I think that this aspect could have been more thoroughly developed. He ends his book with a paragraph on the influence of individuality and the uniqueness of the self on the development of domestic architecture, an important point. While domestic architecture developed in trends, the strength of the individual has had a high degree of impact.

This book is a well-written, engaging introduction to the history of domestic space and its impact on privacy in the home and in the community. Peter Ward has done an adequate job of demonstrating the way in which family and social relationships have transformed Canadian domestic architecture and increased the levels of both personal and family privacy.

Michele L. Gillingham

Memorial University of Newfoundland

The Mountie: From Dime Novel to Disney. By Michael Dawson. (Toronto: Between the Lines, 1998. ISBN 1-896357-16-4, pbk.)

Standing alongside other such icons as the beaver and the maple leaf, the Mountie has actually been both revered and reviled throughout the history of Canada. In his first book, Dawson tackles this most ubiquitous of Canadian symbols. While today we may view the Mountie as a somewhat bland, mildly heroic, brightly uniformed member of a largely ceremonial police force, almost a Canadian version of the Beefeater, this was not always the case. In this insightful and revealing text, Dawson depicts the changing face of the Mountie to both Canadians and those outside our borders.

Dawson takes a historical approach to his subject matter, leading the reader through various pivotal moments in both Canadian and RCMP history. While this initially appears to be his sole theoretical 